\title{
A systematic approach for design of rainwater harvesting system and groundwater aquifer modeling
}

\author{
Mohd. Saleem ${ }^{1} \cdot$ Athar Hussain $^{2} \cdot$ Gauhar Mahmood $^{3}$
}

Received: 24 May 2016 / Accepted: 17 July 2018 / Published online: 9 August 2018

(c) The Author(s) 2018

\begin{abstract}
Shortage of water for industrial and commercial use and even for drinking purpose is a concern throughout the world, especially in developing countries. The current decline in groundwater availability in India necessitates the formulation of sustainable groundwater management plan through proper assessment of the available resources. Rainwater harvesting $(\mathrm{RWH})$ for groundwater recharge is seen as one of the solutions to solve the groundwater problem. This is reflected in an increase in watershed development programs, in which RWH is an important structural component. Understanding the net effect of these development programs is crucial to ensure that net effect on groundwater is positive both locally and within a watershed. The appropriate design and evaluation of a RWH system is necessary to improve system performance and the stability of the water supply. This review article is focused on a literature survey of the design of RWH and its aquifer modeling and application of remote sensing and geographic information system to artificial recharge.
\end{abstract}

Keywords Aquifer $\cdot$ Modeling $\cdot$ Rainwater harvesting $\cdot$ Groundwater

\section{Introduction}

To collect and store rainwater for future various uses, rainwater harvesting $(\mathrm{RWH})$ is a beneficial technique. It is a beneficial technique due to a low-cost solution to water crisis among the community, academic, accomplished, system, incompetent and accomplished in the past few years. Underground water is recharged by artificial recharge techniques (RWH). For solving the water problem of present and future generation, rainwater harvesting is a useful tool in water management. Storing runoff to recharge shallow aquifers using miniature structures is achieved by (RWH) in India. To restore aquifers by (RWH), various literature are highlighted. Various methods, its impacts on groundwater quantity and quality and its modeling are available on (RWH).

Mohd. Saleem

md.saleem0502@gmail.com

1 Faculty of Engineering and Technology, Jamia Millia Islamia, University Polytechnics, New Delhi 110025, India

2 School of Engineering, Gautam Buddha University, Greater Noida, U.P. 201308, India

3 Department of Civil Engineering, Faculty of Engineering and Technology, Jamia Millia Islamia, New Delhi 110025, India
Initially, various issues such as the application of remote sensing (RS) and geographic information system (GIS) in artificial recharge studies, recharge evaluation and groundwater modeling are covered. Basic issues such as (RWH) implementation and its impact are carried out in this review paper (http://shodhganga.inflibnet.ac.in/bitstream/10603).

\section{Estimation of groundwater recharge}

Recharge is defined as the vertical flow of water joining the water table, adding to the groundwater storage. Recharge is normally expressed as the volume per unit time such as $\mathrm{m}^{3} /$ day. Rainfall recharge, return flow from the surface and groundwater irrigation, seepage from tanks and ponds and seepage from canals are various elements of recharge. For efficient management of the groundwater resource, the analysis of the natural recharge is necessary (https://books .google.co.in). To assess the recharge quantitatively, many literatures have achieved. Korkmaz (1988) evaluated the groundwater recharge from water level and precipitation data. During the period of 1975-1984, the average annual recharge was found $180 \mathrm{~mm}$. The average annual rainfall was found 33\% (https://www.revolvy.com/main/index .php?s=\%C3\%87avdarhisar). 
Chiew et al. (1992) predicted the combined surface and groundwater modeling methods for groundwater recharge. The potentiometric head and streamflow data were measured by this model. They explained the model to the Campaspe River Basin in North-Central Victoria, and the results determined that this modeling access can estimate satisfactorily the spatial and temporal distribution of local recharge rates resulting from rainfall and irrigation water. They examined that the integrated model was better than those forecasted when the groundwater and surface models were used separately. Osterkamp et al. (1995) analyzed the groundwater recharge estimation in arid and semiarid areas by examples from Abu Dhabi.

In South Africa, Bredenkamp et al. (1995) explained the dramatic aquifers by taking the cumulative rainfall departure (CRD) method. They examined the migration of rainfall from the mean rainfall of the preceding time is concerned with the natural ground-level fluctuation. If the migration is positive, then the water level will increase and vise versa (Xu and van Tonder 2001). Giambelluca et al. (1996) considered the uncertainty in recharge assessment and impact on groundwater susceptibility estimates for Pearl Harbor Basin, $\mathrm{O}$ 'ahu, Hawai ' $\mathrm{i}$, USA. They investigated the recharge uncertainties for agricultural land under pineapple or sugarcane cultivation by taking a combination of first-order sensation analysis and ambiguity analysis. By taking unpredictability, the recharge was found 58\% for pineapple and $49 \%$ for sugarcane (Giambelluca et al. 1996).

Finch (1998) estimated the direct groundwater recharge by taking simple water balance model. They discussed varying the vegetation sunshade parameters for the forest in addition to varying the soil moisture model (Finch 1998). Amitha (2000) estimated natural ground recharge by using various techniques such as zero flow plane method, soil water balance method, inverse modeling method and onedimensional soil water flow model (Kumar 1997), groundwater-level fluctuation method, isotope and solute profile techniques, compound water fluctuation method and groundwater balance method. Kichurl (2001) estimated the groundwater recharge rate for fractured hard rock aquifer, Chojeong area, South Korea. Six different methods were taken to estimate groundwater recharge rate including Soil Conservation Service-Curve Number Method (SCS-CN) design, multilinear regression analysis and aquifer modeling techniques. The researchers suggested that SCS-CN and flood formula are more suitable for the top unconfined aquifer, which had various hydraulic conductivity including lower fractured hard rock formation; the recharge rates achieved from those analytical models are twice that value from aquifer model (Kichurl 2001). For estimation of recharge, amended cumulative rainfall departure (CRD) method was used. Xu and Van Tonder (2001) evaluated the periodicities and the trends in the rainfall, which was not examined in Bredenkamp formula. Recharge Estimation Model in Excel (REME) was promoted in this study (Xu and van 2001). Moon et al. (2004) evaluated groundwater recharge in South Korea by taking the statistical investigation of water table fluctuation and hydrographs. Groundwater hydrographs were classified into five typical groups by taking water table observation data from the National Groundwater Monitoring Network in Korea. To estimate groundwater recharge, an altered water table fluctuation (WTF) method was developed between the corresponding rainfall reports and cumulative WTF (Moon et al. 2004).

Baalousha (2005) examined quantification of groundwater recharge in the Gaza Strip, Palestine by taking the CRD method. To minimize the root mean squared error (RMSE), the CRD method was carried out between the assumed groundwater head and measured head. The results correlated with the results of other recharge estimation methods from the literature. It was suggested that the results obtained by this method are very close to the results of the other methods (Baalousha 2005). Sun (2005) evaluated groundwater recharge evaluation in Montagu region of the western Klein Karoo, South Africa by water balance technique. To consider long-term average recharge, runoff model and experimental evapotranspiration were considered. The long-term average recharge was a function of the site conditions such as soil, climate, territory and geology. The definite evapotranspiration, recharge and direct runoff were quantified by using long-term physical and climatic data from the various precipitations interval of different gauge stations (Sun 2005).

Chand et al. (2005) considered neutron moisture probe for groundwater recharge in Hayatnagar micro-watershed, India. Eight sites of Hayatnagar micro-watershed at regular intervals of time were obtained for the soil moisture integrity (Sandhu et al. 2000). It was found that the overall volume of water (recharge) varies from 0.22 to $0.37 \mathrm{~m}$. The storativity varies from 6.9 to $10.6 \%$ due to rise in water level. Adelana et al. (2005) found groundwater recharge in part of the Sokoto basin, Nigeria, by using hydrochemical, experimental and vital hydrological methods. For estimation of recharge in most of the basin, the chloride mass balance method was most relevant (Adelana and MacDonald 2008). Lorenz and Delin (2007) evaluated regional groundwater recharge by regional regression recharge (RRR) model. To evaluate the recharge from, surface water drainage basins, rainfall, average basin and specific yield (SY) (RRR) model was used. The recharge measured by the RRR technique was also the lowest $(0-5 \mathrm{~cm} /$ year) (Lorenz and Delin 2007).

Delin et al. (2007) evaluated the groundwater recharge in Minnesota, USA, using three regional-scale approaches (water table fluctuations (WTF), unsaturated-zone water balance and age dating of groundwater). It was concluded that the WTF method was the easiest and quietest to apply for recharge calculation (Delin et al. 2007). Rasoulzadeh 
and Moosavi (2007) examined groundwater recharge in the proximity of Tashk Lake by using CRD method. Groundwater recharge estimation technique (GRET) was used to reduce the difference between the detected water table and simulated elevations. For high volume of groundwater evocation in the study area, the natural recharge is not sufficient (Rasoulzadeh and Moosavi 2007).

Bingguo et al. (2008) examined groundwater recharge in Hebei Plain, China by tritium and bromide tracers. Tritium and bromide tracing was used for recharge coefficient and normal recharge rates. It was found that this method is useful for the deep water table (Bingguo et al. 2008). Sibanda et al. (2009) correlated the groundwater recharge estimation methods for the semiarid Nyamandhlovu area, Zimbabwe by using chloride mass balance method. The flow net estimations and modeling methods provided improved estimates for aerial recharge than the alternative methods. Based on groundwater modeling, a final recharge (from precipitation) was evaluated to be $15-20 \mathrm{~mm} /$ year (Love et al. 2010).

For recharge evaluation based on a water balance approach, Government of India has confined a set of guidelines through a Groundwater Resource Estimation Committee (GWREC 2009). Different values are to be taking from pumping test analysis. Groundwater storage increase could be estimated by using the variation in specific yield, groundwater level and area of effect (Kumar 2009). Adnan (2010) determined groundwater recharge modeling using WetSpass model for Gaza strip, Palestine. For evaluation of long-term average spatial patterns of absolute evapotranspiration, surface runoff and groundwater recharge, the WetSpass model was developed (Adnan 2010). Izuka et al. (2010) interpreted groundwater recharge on tropical islands by simple equations. Equations were used for recharge estimates from soil intrusion, and infiltration, and preceding soil water budget studies in Hawai, USA (Izuka et al. 2010).

Chandra et al. (2011) evaluated spatiotemporal recharge circulation in crystalline rocks of Bairasagara watershed and Maheshwaram watershed of India by lithologically constrained rainfall (LCR) method. Three input parameters, i.e., vadose zone thickness, soil resistivity and rainfall were used in lithologically constrained rainfall (LCR) technique. It was evaluated in the study that the LCR is a generalized, fast method and cost effective also to evaluate natural recharge partially and temporally from rainfall in hard rock region and construct a useful time series of natural recharge in the studied watershed for foretelling studies (Chandra et al. 2011).

Srinivas et al. (2011) determined the stage of groundwater development in Kurmapalli Vagu Basin in Deccan Plateau by exercising remote sensing and geographical information system techniques in conjunction with typical methods. Groundwater recharge from canals, rainfall, minor irrigation tanks recovery flow of irrigation and water management structures were estimated. The overall groundwater recharge and annual utilizable groundwater resources from different sources were measured. The groundwater balance of the basin achieved 1.95 MCM. The stage of groundwater development achieved to $80.6 \%$ which falls in the semi-critical category (Pradeep Kumar and Srinivas 2012). Mondal et al. (2011) delimited prospective groundwater recharge zones in a hard rock area from Southern India by RS and GIS techniques. They achieved the validation of estimated recharge values using the modified water table fluctuation (WTF) method (Mondal et al. 2011).

From the various literature studies, it is understood that one must understand water resources management that how much water is recharging the groundwater aquifers. Therefore, the GWREC (2009) methodology is adopted for this study.

\section{Application of remote sensing and GIS for artificial recharge}

GIS and RS are very efficient tools for integrating urban planning and groundwater recharge studies. Satellite data are very useful in controlling the occurrence and movement of groundwater like geomorphology, structural, land use/land cover, soil and features. RS and GIS are very useful tools in artificial recharge modeling (Mondal 2012). Ramasamy and Anbazhagan (1997) identified suitable sites for artificial recharge in Ayyar sub-basin in Cauvery River, India by collecting the data of water-level variation, omphalic, geology and subsurface geology. Favorable sites for various artificial recharge structures were differentiated (Ramasamy and Anbazhagan 2014).

Saraf and Choudhury (1998) defined the groundwater exploration and identification of artificial recharge sites in hard rock terrain in the Sironj area of Vidhisha District, India by the potentials of integrated RS and GIS. The study shows reservoir-induced artificial recharge downstream of surface water reservoirs. Groundwater recharge in a hard rock region through recharge basins or reservoirs was selected by proper sites (Saraf and Choudhury 2007). Kshirish et al. (2002) defined the parameters like drainage, surface contour, tendency and groundwater depth by using RS and GIS for Rengareddy District, Andhra Pradesh. A clear picture of the recharge areas was concluded by this study (Kannan 2007).

Shankar and Mohan (2005) considered the site-specific artificial recharge methods in the Deccan Volcanic Province of India by the GIS-based hydrogeomorphic approach. The hydrogeomorphological characteristics extracted from the IRS-1C LISS-III (Indian Remote Sensing-1C Linear Imaging Self Scanner-III) were adopted for GIS analysis. Check dams and percolation ponds structures were recommended for artificial recharge (Shankar and Mohan 2005). De Winnaar et al. (2007) considered the potential runoff 
harvesting sites in the Thukela River Basin, South Africa by GIS technique. Probable runoff harvesting sites were identified by GIS (Anderssona et al. 2011). Mbilinyi et al. (2007) considered the potential sites for rainwater harvesting in Tanzania by GIS-based decision support system (DSS). Maps of rainfall, soil texture, slope, soil depth and drainage and land use data were collected by DSS (Below et al. 2007).

Ghayoumian et al. (2007) determined most suitable regions for artificial groundwater recharge in a coastal aquifer in Southern Iran by GIS technique. Infiltration rate, confined layers for slope, quality of alluvial sediments, depth to groundwater and land use were examined for completed and integrated into a GIS environment (Xiaojun 2009). Lin et al. (2009) determined groundwater recharge and discharge evaluation by PRO-GRADE GIS toolkits. The mass balance technique such as water table, hydraulic conductivity and ground elevation data was used for GRADE GIS (Lin et al. 2009). Maggirwar and Umrikar (2009) established the possibility of artificial recharge in overdeveloped small watersheds by RS-GIS technique. Village map, drainage map, geomorphology, soil map and land used were prepared for confined aquifers (Maggirwar and Umrikar 2009).

Sukumar and Sankar (2010) delineated the possible zones for artificial recharge in Theni district, Tamilnadu by using GIS technique. Moderate, high and least favorable zones were prepared for artificial recharge. Soil depth, permeability, drainage intensity, soil texture and water holding capacity maps were prepared for different confined layers (Nagaraju et al. 2010). Peiyue et al. (2011) examined the artificial recharge regions in Sivaganga District, Tamilnadu by using the RS and GIS techniques. Various confined maps such as drainage, lineament, drainage density, lineament density, land use, geomorphology, land cover and Landsat satellite data were prepared. For updating the confined maps, the normalized difference vegetation index (NDVI) methods were prepared for all integrated and confined maps (Peiyue et al. 2011).

Chowdhury et al. (2010) described the RS, GIS and multi-criteria decision making (MCDM) methods for groundwater recharge zones and to identify the artificial recharge sites in West Medinipur district, West Bengal. Conventional and IRS-1D imagery data were prepared for confined layers. Based on the available field information, check dams were proposed for artificial recharge structures (Chenini 2010). RS and GIS are a very useful technique for groundwater recharge studies. To define the potential groundwater recharge zones, artificial groundwater recharge must be implemented.

\section{Groundwater modeling}

To predict recharge of groundwater, the practical management of groundwater is very necessary. For estimating flow and recharge in groundwater systems, the deterministic, assigned-parameter, computer simulation models a very popular tool. Equations, constants or coefficients of physical properties in the equations and amplitudes of the state are performed by mathematical models (Delleur 2003). Conservation of mass, energy and momentum is based on mathematical groundwater models. To determine the necessity of artificial recharge, a mathematical model can be used as a design tool. Many researchers around the world have attempted to carry out groundwater recharge modeling. Bekesi and McConchie (2003) used Monte Carlo technique for Manawatu region of New Zealand for groundwater recharge modeling. In this study, a regional rainfall recharge model was developed. For the basic variability of soils, randomized soil moisture parameters were used. Good agreement between the modeled and actual groundwater levels was obtained (Ekesi and McConchie 2000).

Gnanasundar and Elango (2000) carried out the groundwater flow modeling of a marginal aquifer near Chennai city, India using MODFLOW. The model was measured under steady and transient conditions. The structural distribution of groundwater head and well hydrograph was differentiated from the historic data. They achieved that rapid urbanization would lead to further lowering of the water table at few locations along the Northern coast of the aquifer system. They also indicated that their model is delicate even for 5\% reduction in recharge (Gnanasundar and Elango 2011). Gogu et al. (2001) performed groundwater modeling of Belgium for the Walloon region by using the GIS-based hydrogeological database. Different hydrogeological characteristics of five river pool were chosen in the database. A "loose-coupling" device was estimated between the groundwater numerical model interface Groundwater Modeling System (GMS) and the structural-data base plan. Stored data in the database of hydrogeological data can be used easily for structural queries and following time within different groundwater numerical models (Wojda et al. 2006).

Pliakas et al. (2005) examined the groundwater recharge of Bedin Xanthi plain, Greece by reactivating an old stream. MODFLOW was used to copy the aquifer system of the study area (Katpal et al. 2013). Fayez and Tamer (2006) examined groundwater flow for Mujib aquifer of Jordan by using MODFLOW technique. The affect of the flow system under various stresses was examined, and MODFLOW model was used to build a groundwater flow technique. The steady-state condition of the initial head 


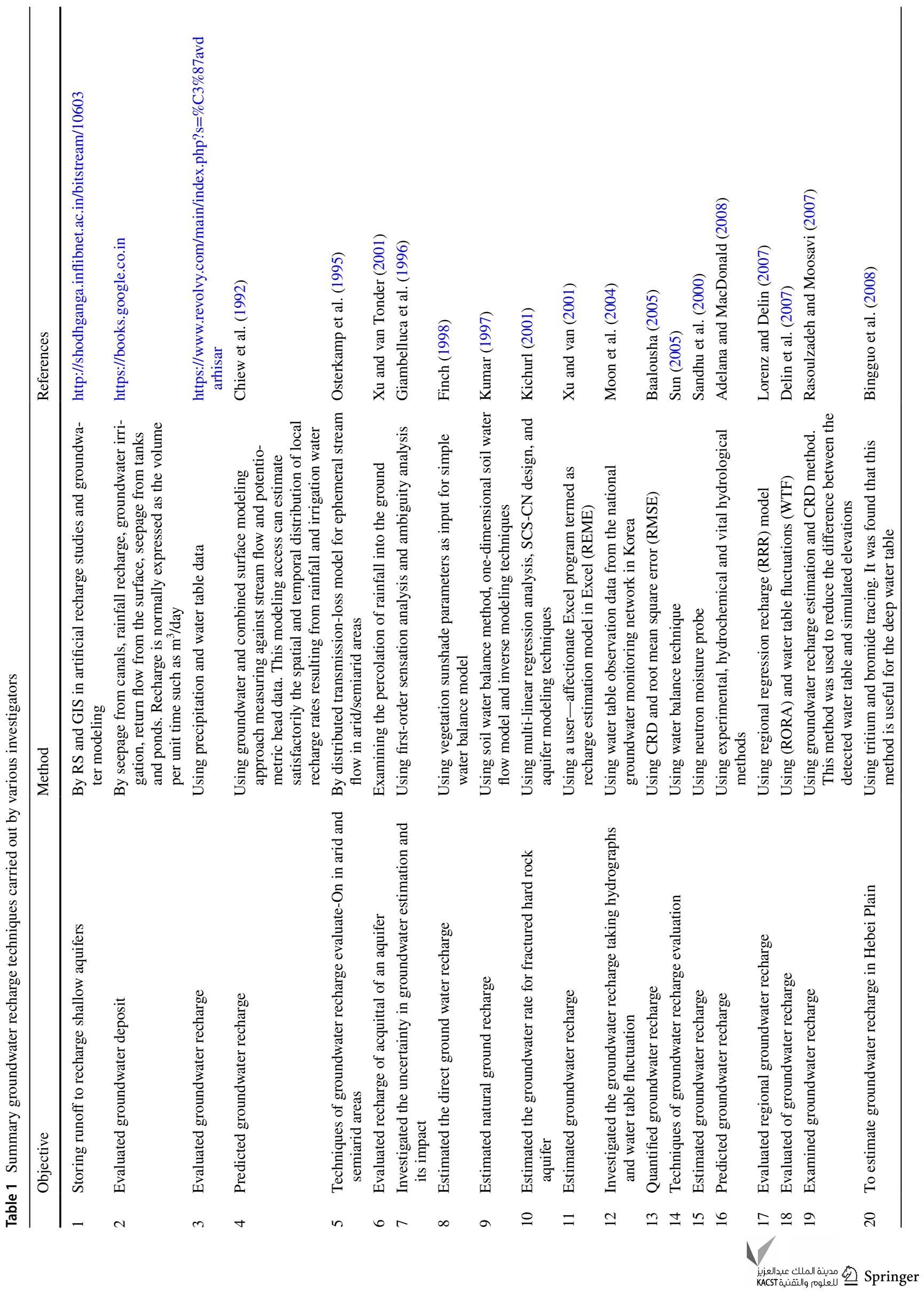




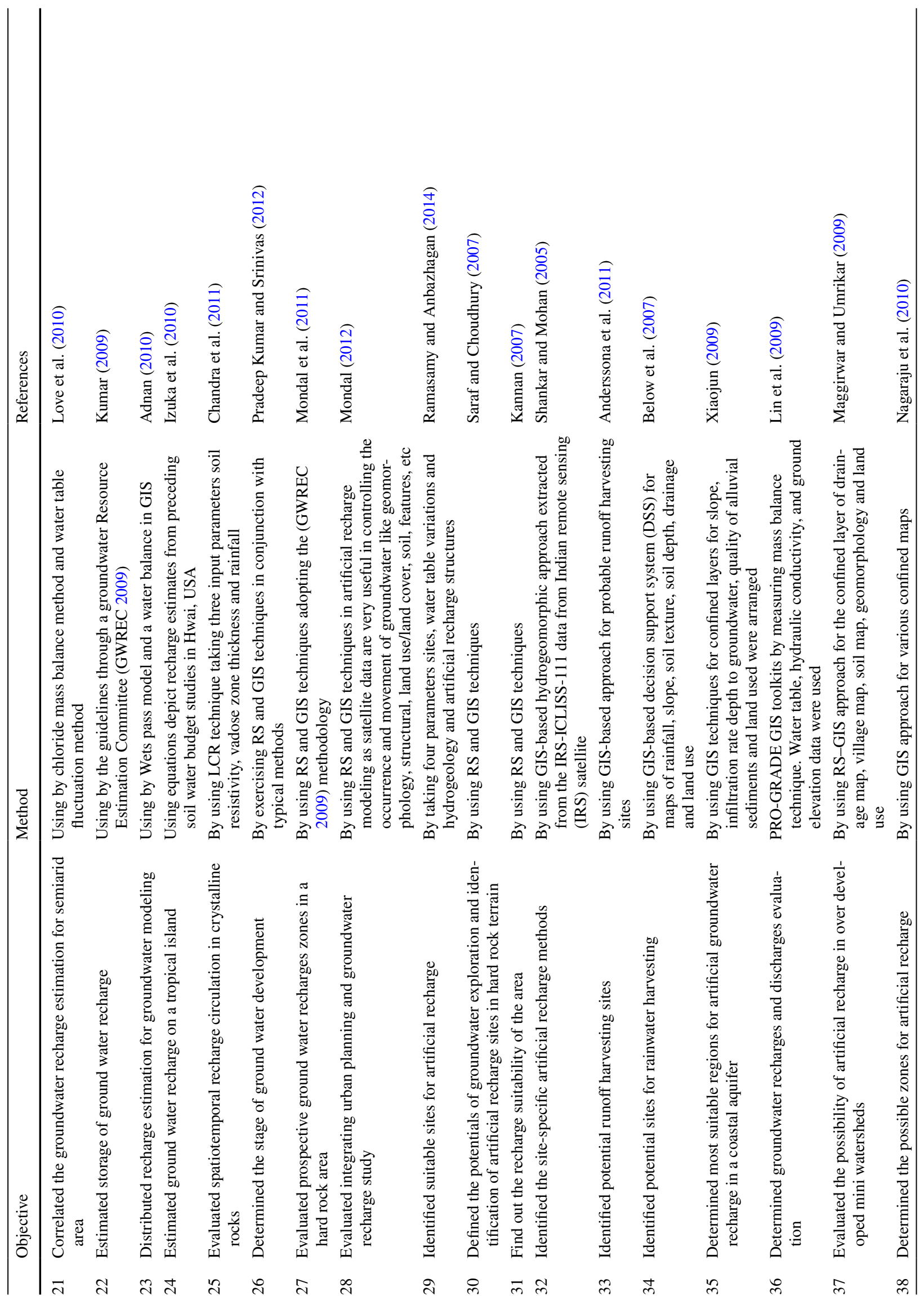




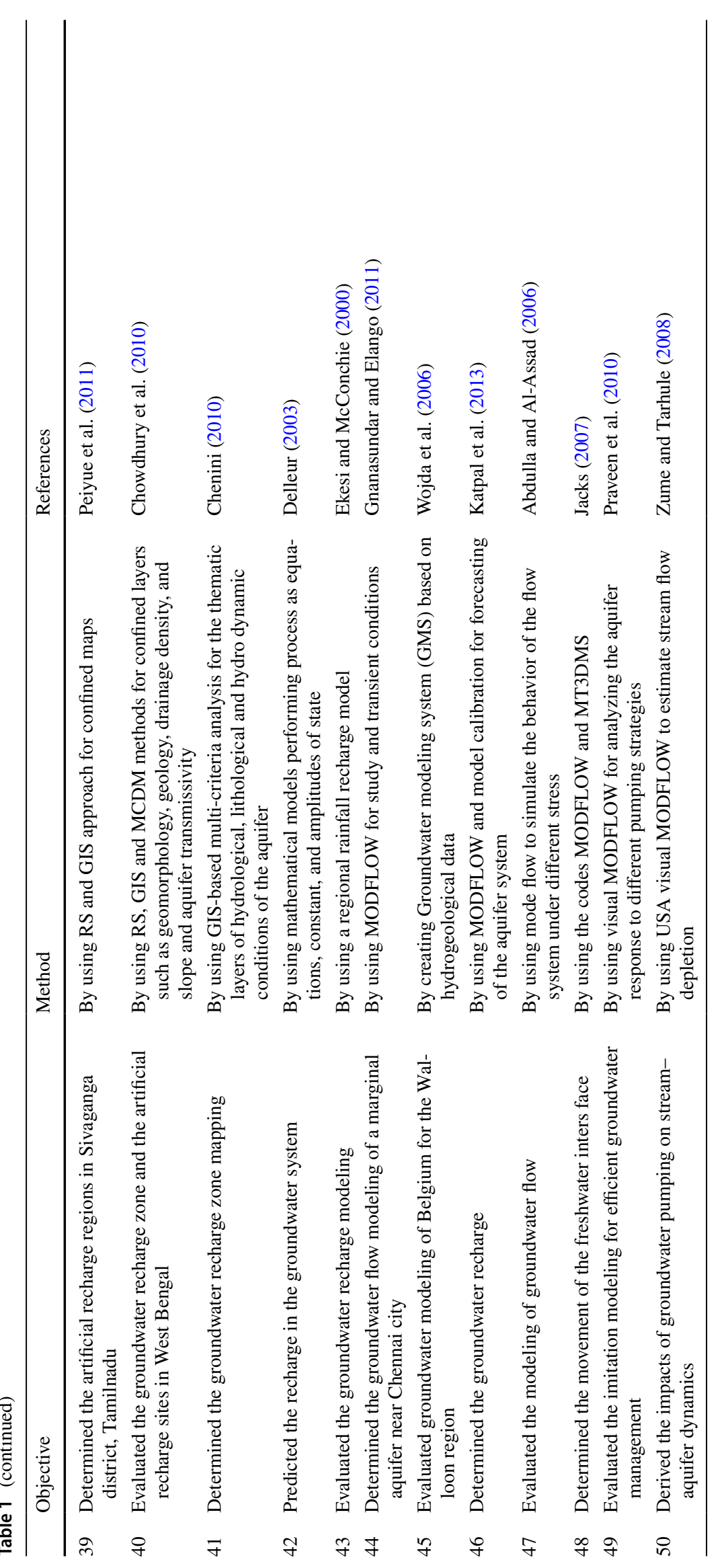


contour lines was measured by MODFLOW model. The affect of the drawdown of a well was examined and used this data to calibrate the temporary model. To predict aquifer system response under different environment various scenarios were forecasting (Abdulla and Al-Assad 2006). Shammas and Jacks (2007) determined the movement of the freshwater/saltwater interface by using the codes MODFLOW and MT3DMS for solute transport. The protection of the groundwater in Salalah plain aquifer in Oman from further intrusion by an artificial recharge with reclaimed water along the Salalah coastal agricultural strip was recommended (Jacks 2007).

Rejani et al. (2008) estimated the efficient groundwater management in Balasore Coastal Basin, India by Visual MODFLOW technique. It was found that the recharge from rainfall, river seepage and inflow than to horizontal and vertical hydraulic conductivities and definite storage is very easy in the Balasore aquifer system (Praveen et al. 2010). Zume and Tarhule (2008) used MODFLOW technique for the impacts of groundwater pumping on stream-aquifer dynamics in semiarid Oklahoma, USA. Pumping-induced changes in base flow, stream flow total package and stream leakage were evaluated by MODFLOW to estimate stream flow depletion in the Beaver-North Canadian river system (Zume and Tarhule 2008) (Table 1).

\section{Conclusions}

Different techniques of RWH along with its impact, various methods of recharge, use of RS, GIS and models in artificial recharge were reviewed. It helped to learn the past RWH implementation experiences around the world and the different way that are likely to provide the most quantitative estimates of recharge. From the various literature, it has been identified that various researchers handled different objectives with different methodologies and identified that all the works done are at the initial levels, so there is a need to handle the different issues of groundwater recharging by applying the rainwater harvesting techniques which are major challenges these days.

Open Access This article is distributed under the terms of the Creative Commons Attribution 4.0 International License (http://creativeco mmons.org/licenses/by/4.0/), which permits unrestricted use, distribution, and reproduction in any medium, provided you give appropriate credit to the original author(s) and the source, provide a link to the Creative Commons license, and indicate if changes were made.

\section{References}

Abdulla F, Al-Assad T (2006) Modeling of groundwater flow for Mujib aquifer, Jordan. J Earth Syst Sci 115(3):289-297

Adelana S, MacDonald A (eds) (2008) Applied groundwater studies in Africa. CRC Press/Balkema, London, UK

Adelana S, Olasehinde P, Vrbka P (2005) Identification of groundwater recharge conditions in crystalline basement rock aquifers of the southwestern Nigeria. International symposium on mixed and augmented reality, 5th international symposium

Adnan M (2010) Antimicrobial potential of alkaloids and flavonoids extracted from tamarix aphylla leaves against common human pathogenic bacteria. Afr J Tradit Complement Altern Med 12(2):27-31

Amitha K (2000) Estimation of natural ground water recharge, lake 2000: national conference. Indian Institute of Science, Bangalore, Nov 27-29

Anderssona JCM, Zehnder AJB, Rockströme J, Yanga H (2011) Potential impacts of water harvesting and ecological sanitation on crop yield, evaporation and river flow regimes in the Thukela River basin. S Afr Agric Water Manag 98:1113-1124

Baalousha H (2005) Using CRD method for quantification of groundwater recharge in the Gaza Strip. Palest Environ Geol 49:634-635

Bekesi G, McConchie J (2003) Empirical assessment of the influence of the unsaturated zone on aquifer vulnerability, Manawatu Region, New Zealand. Groundwater 38(2):193-199

Below T, Artner A, Siebert R, Sieber S (2007) Micro-level practices to adapt to climate change for african small-scale farmers. A review of selected Literature. IFPRI discussion paper 00953. Environment and Production Technology Division, International Food Policy Research Institute

Bingguo W, Jin M, Nimmo JR, Yang L, Wang W (2008) Estimating groundwater recharge in Hebei Plain, China under varying land use practices using tritium and bromide tracers. J Hydrol 356:209-222

Bredenkamp GJ, Bezuidenhout H (1995) A proposed procedure for the analysis of large phytosociological data sets in the classification of South African grasslands. Koedoe 38(1):33-39

Chand D, Hachey G, Hunton J, Owhoso V, Vasudevan S (2005) A balanced scorecard based framework for assessing the strategic impacts of ERP systems. Comp Industry 56:558-572

Chandra S, Ahmed S, Rangarajan R (2011) Lithologically constrained rainfall (LCR) method for estimating spatio-temporal recharge distribution in crystalline rocks. J Hydrol 402:250-260

Chenini I (2010) Groundwater recharge study in arid region: an approach using GIS techniques and numerical modeling. Comput Geosci 36:801-817

Chiew FHS, McMahon TA, O'Neill IC (1992) Estimating groundwater recharge using an integrated surface and groundwater modelling approach. J Hydrol 131:151-186

Chowdhury A, Jha MK. Chowdary VM (2010) Delineation of groundwater recharge zones and identification of artificial recharge sites in West Medinipur district, West Bengal, using RS, GIS and MCDM techniques. Environ Earth Sci 59:1209-1222

Delin GN, Healy RW, Lorenz DL, Nimmo JR (2007) Comparison of local to regional scale estimate of groundwater. J Hydrol 334:231-249

Delleur V (2003) Earthquake dates water level changes in wells in the Eskehiser region, Turkey. Hydrol Earth Syst Sci 7:771-781

Ekesi G, McConchie J (2000) Empirical assessment of the influence of the unsaturated zone on aquifer vulnerability, Manawatu region, New Zealand. Groundwater 38:193-199. https://doi. org/10.1111/j.1745-6584.2000.tb00330.x 
Finch JW (1998) Estimating direct groundwater recharge using a simple water balance model - sensitivity to land surface parameters. J Hydrol 211:112-125

Ghayoumian J, Saravi MM, Feiznia S, Nouri B, Malekian A (2007) Application of GIS techniques to determine areas most suitable for artificial groundwater recharge in a coastal aquifer in southern Iran. J Asian Earth Sci 30(2):364-374

Giambelluca T, Loague K, Green RE, Nullet MA (1996) Uncertainty in recharge estimation: impact on groundwater vulnerability assessments for the Pearl Harbor Basin. J Contam Hydrol 23:85-112

Gnanasundar D, Elango L (2011) Numerical modelling of groundwater flow in south Chennai coastal aquifer. Groundw Dyn Hard Rock Aquifers 3:234-242

Gogu R, Carabin G, Hallet V, Peters V, Dassargues A (2001) GIS-based hydrogeological databases and groundwater modelling. Hydrogeol J 9(6):555-569

GWREC (2009) Ground Water Resource Estimation Committee Report, 2006

http://shodhganga.inflibnet.ac.in/bitstream/10603, CHAPTER 2, pp 13-43. Accessed 24 July 2018

Izuka SK, Oki DS, John A (2010) Engott simple method for estimating groundwater recharge on tropical islands. J Hydrol 387(1-2):81-89

Jacks S (2007) SEA water intrusion in the Salalah plain aquifer, OMAN. J Environ Hydrol 15:575-587

Kannan S (2007) Groundwater augmentation plan for a degraded Western Ghat Terrain using Remote Sensing and Gis. Thesis Kerala Agricultural University

Katpal Y, Lamsoge B, Pophare AM (2013) A groundwater flow model for overexploited basaltic aquifer and Bazada formation in India. Environ Earth Sci. https://doi.org/10.1007/s12665-014-3342-2

Kichurl et al (2001) Review of literature. http://shodhganga.inflibnet. ac.in/bitstream/10603/15818/7/07_chapter\%202.pdf. Accessed 24 July 2018

Kshirish K, Santhosh K, Kyatham K (2002) Delineation of recharge zones for groundwater using GIS. Proc Int Conf Hydrol Watershed Manage 2:530-535

Kumar CP (1997) Estimation of natural groundwater recharge. ISH J Hydraul Eng 3(1):61-74

Kumar A (2009) Report of the Ground Water Resource Estimation Committee, Ground Water Resource Estimation Methodology, Ministry of Water Resources Government of India, New Delhi

Kutahya-Çavdarhisar Aegean region of Turkey. https://www.revol vy.com/main/index.php?s=\%C3\%87avdarhisar. Accessed $12 \mathrm{Jan}$ 2018

Korkmaz N (1998) The estimation of groundwater recharge from water level and precipitation data. J Islam Acad Sci 1(2):87-93

Lin W, Zhang M, Wu J (2009) Simulation of low clouds from the CAM and the regional WRF with multiple nested resolutions. Geophys Res Lett 36:L08813. https://doi.org/10.1029/2008GL037088

Lorenz DL, Delin GN (2007) A regression model to estimate regional ground water recharge. Groundwater 45(2):196-208

Love D, Uhlenbrook S, Corzo-Perez G, Twomlow S, Van Der Zaag P (2010) Rainfall-interception-evaporation-runoff relationships in a semi-arid catchment, Northern Limpopo Basin, Zimbabwe. Hydrol Sci J 55(5):687-703

Maggirwar BC, Umrikar BN (2009) Possibility of artificial recharge in overdeveloped miniwatersheds: RS-GIS approach. e J Earth Sci 2(2):101-110

Mbilinyi BP, Tumbo SD, Mahoo HF, Mkiramwinyi FO (2007) GIS-based decision support system for identifying potential sites for rainwater harvesting. Phy Chem Earth Parts A/B/C 32(15-18):1074-1081

Mondal S (2012) Remote sensing and GIS based ground water potential mapping of Kangshabati irrigation command area, West Bengal. J Geogr Nat Disast 1:1
Mondal BC, Mukherjee T, Mandal L, Evans CJ, Sinenko SA, MartinezAgosto JA, Banerjee U (2011) Interaction between differentiating cell- and niche-derived signals in hematopoietic progenitor maintenance. Cell 147(7):1589-1600

Moon SK, Woo NC, Lee KS (2004) Statistical analysis of hydrograph and water-table fluctuation to estimate groundwater. J Hydrol 292:198-209

Nagaraju D, Nassery HR, Adinehvandi R (2010) Determine suitable sites for artificial recharge using hierarchical analysis (AHP), remote sensing (RS) and geographic information systems (GIS). Int J Earth Sci Eng 5(5):1328-1335

Osterkamp WR, Lane LJ, Menges CM (1995) Techniques of groundwater recharge estimates in arid/semi-arid areas, with examples from Abu Dhabi. J Arid Environ 31(3):349-369

Peiyue L, Quan W, Jianhua W (2011) Groundwater suitability for drinking and agricultural usage in yinchuan area, China. Int $\mathbf{J}$ Environ Sci 1:1241-1249

Pliakas F, Petalas C, Diamantis I, Kallioras A (2005) Modeling of groundwater artificial recharge by reactivating an old stream bed. Water Resour Manage 19(3):279-294

Pradeep Kumar GN, Srinivas P (2012) Evaluation of groundwater resources and estimation of stage of groundwater development in a basin - a case study, irrigation and drainage. Irrig Drain 61:129-139

Praveen SM, Abdullah MH, Aris AZ (2010) Modeling for equitable groundwater management. Int J Environ Res 4(3):415-426

Ramasamy SM, Anbazhagan S (1997) Geophysical resistivity survey and potential site selection for artificial recharge in central Tamil Nadu, India. In: Proceedings of international symposium on engineering geology and the environment (IAEG), Athens, Greece, pp 1169-1173

Ramasamy SM, Anbazhagan S (2014) Remote sensing and GIS are playing a rapidly increasing role in the field of hydrology. Int $\mathbf{J}$ Pure Appl Res Eng Technol 2(9):21-34

Rasoulzadeh A, Moosavi SAA (2007) Study of groundwater recharge in the vicinity of Tashk Lake area. Iran J Sci Technol 31(B5):509-552

Rejani R, Jha MK, Panda SN, Mull R (2008) Simulation modeling for efficient groundwater management in Balasore coastal basin, India. Water Resour Manage 22:23-50

Richard W Estimating groundwater recharge. Healy https://books.googl e.co.in. Accessed 24 July 2018

Sandhu KS, Arora VK, Ramesh C, Sandhu BS, Khera KL (2000) Optimising time distribution of water supply and fertilizer nitrogen rates in relation to targeted wheat yield. Exp Agric 36:115-125

Saraf AK, Choudhury PR (1998) Integrated remote sensing and GIS for groundwater exploration and identification of artificial recharge sites. Int J Remote Sens 19:1825-1841. https://doi. org/10.1080/014311698215018

Saraf AK, Choudhury A (2007) Delineation of groundwater recharge sites using integrated remote sensing and GIS in Jammu district, India. Int J Remote Sens 28(22):5019-5036

Shankar R, Mohan A (2005) GIS-based hydrogeomorphic approach for identification of site-specific artificial-recharge techniques in the Deccan Volcanic Province. J Earth Syst Sci 114(5):505-514

Sibanda T, Nonne JC, Uhlenbrook S (2009) Comparison of groundwater recharge estimation methods for the semi-arid Nyamandhlovu area, Zimbabwe. Hydrogeol J 17(6):1427-1441

Srinivas P, Pradeep Kumar P, Srinivasa Prasad A, Hemalatha T (2011) Generation of groundwater quality index map - a case study. Civ Environ Res 1(2)

Sukumar S, Sankar K (2010) Delineation of potential zones for artificial recharge using GIS in Theni district, Tamilnadu, India. Int J Geomat Geosci 1(3):639-648

Sun X (2005) A water balance approach to groundwater recharge estimation in montagu area of the Western Klein Karoo. University

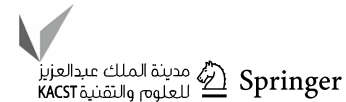


of the Western Cape, Bellville, South Africa, Department of Earth Sciences, Bellville

Winnaar G, Jewitt GPW, Horan M (2007) A GIS-based approach for identifying potential runoff harvesting sites in the Thukela River basin, South Africa. Phy Chem Earth Parts A/B/C 32(15):1058-1067

Wojda P, Gogu R, Brouyère S (2006) Conceptual model of hydrogeological information for a GIS-based Decision Support System in management of artificial recharge in semi-arid regions. In: International association for mathematical geology XIth international congress Université de Liège-Belgium

Xiaojun Y (2009) Remote sensing and geospatial technologies for coastal ecosystem assessment and management. Lecture notes in geoinformation and cartography. Springer, Berlin, Heidelberg
Xu Y, van GJ (2001) Estimation of recharge using a revised CRD method Tonder. http://www.wrc.org.za

$\mathrm{Xu}$ Y, van Tonder GJ (2001) Estimation of recharge using a revised CRD method. Water SA 27(3):341-343

Zume J, Tarhule A (2008) Simulating the impacts of groundwater pumping on stream-aquifer dynamics in semiarid northwestern Oklahoma, USA. Hydrogeol J 16(4):797-810

Publisher's Note Springer Nature remains neutral with regard to jurisdictional claims in published maps and institutional affiliations. 